The 30th Lung Cancer Mass Screening Seminar

胸部 X 線写真

一正常と異常影を見極める一

\title{
藤澤英文1
}

\section{How to Differentiate Normal from Abnormal Imaging Findings on Chest Radiographs}

Hidefumi Fujisawa1

${ }^{1}$ Department of Radiology, Showa University Northern Yokohama Hospital, Japan.

ABSTRACT - Objective. The aim of this paper is to learn about the pitfalls in lung nodule detection on a posteroanterior chest radiographs, to understand the imaging findings of mimicking lung nodules, and to reveal various types of pseudolesion. Methods. Many cases that I have experienced are shown and outlined. Results. Various pitfalls in the diagnosis of chest radiographs are included, such as a lung nodule overlapped by a lung apex, an underdiaphragm, and a mediastinum. We should be aware of the findings that mimic lung nodules, such as the ossification of the first rib cartilage, nipple shadows, apical opacity, azygos lobes, bone islands, and osteophytes. Pseudolesions include normal variants such as pericardial fat pads, aortic nipples, rib anomalies, deformation of the normal anatomical structures, the shadow of an object on the skin, and characteristic chest X-ray shadows. Conclusion. It is important to be aware of the many pitfalls on chest radiographs, the findings that mimic lung nodules, and pseudolesions. This will enable the precise diagnosis of lung nodules on chest radiographs.

KEY WORDS — Chest radiograph, Lung nodule, Lung cancer, Normal variant, Pitfall

(JJLC. 2016;56:232-241)

Corresponding author: Hidefumi Fujisawa.

要旨一一目的. 胸部 X 線写真正面像において, 肺結節 を見逃しやすいピットフォール，肺結節と見誤りやすい 画像所見，異常影と正常を鑑別するために知っておきた い偽病変を学ぶこと. 方法. 自験例をもとに多くの症例 を供覧して概説する. 結果. ピットフォールには肺尖, 横隔膜下, 縦隔影に重なる肺結節, 気管腫瘍などがある. 肺結節と見誤りやすい所見には第 1 肋軟骨骨化, 乳頭陰 影, apical opacity, 奇静脈葉, 骨島, 骨棘などを知って
おくと良い. 偽病変には心膜外脂肪塊や aortic nipple などの正常破格, 肋骨などの奇形, 腕頭動脈蛇行などの 変形, 皮覤上の異物, 皮膚媰や頭髪などの X 線撮影特有 の所見などがある. 結論. 胸部 X 線写真のピットフォー ル, 肺結節類似所見, 偽病変を知っておくことで, 肺結 節を正しく検出できる.

索引用語——胸部 $\mathrm{X}$ 線, 肺結節, 肺癌, 正常破格, ピッ トフォール

\section{はじめに}

胸部 X 線写真は, 胸部領域全体像の把握と経時変化の 観察が容易であるという大きな特徵を有する。しかも簡 便に施行でき，低コストで被ばく線量は低い。したがっ て画像診断が発達した現在でも, 肺がん診療において胸 部 X 線写真の果たす役割はいまだに重要である.胸部 X
線写真の役割は，1）病変検出，2）見いだされた病変に ついて良悪性判定と鑑別診断，3）診療方針決定，4）治 療後の経過観察，5）合併症診断，などであろう.

本稿は第 30 回肺がん集検セミナーの講演内容の一部 で, 胸部 X 線写真で肺結節を見落としやすいピット フォール，肺結節と見誤りやすい所見，異常影を見極め るために知っておきたい偽病変について, 症例を供覧し 


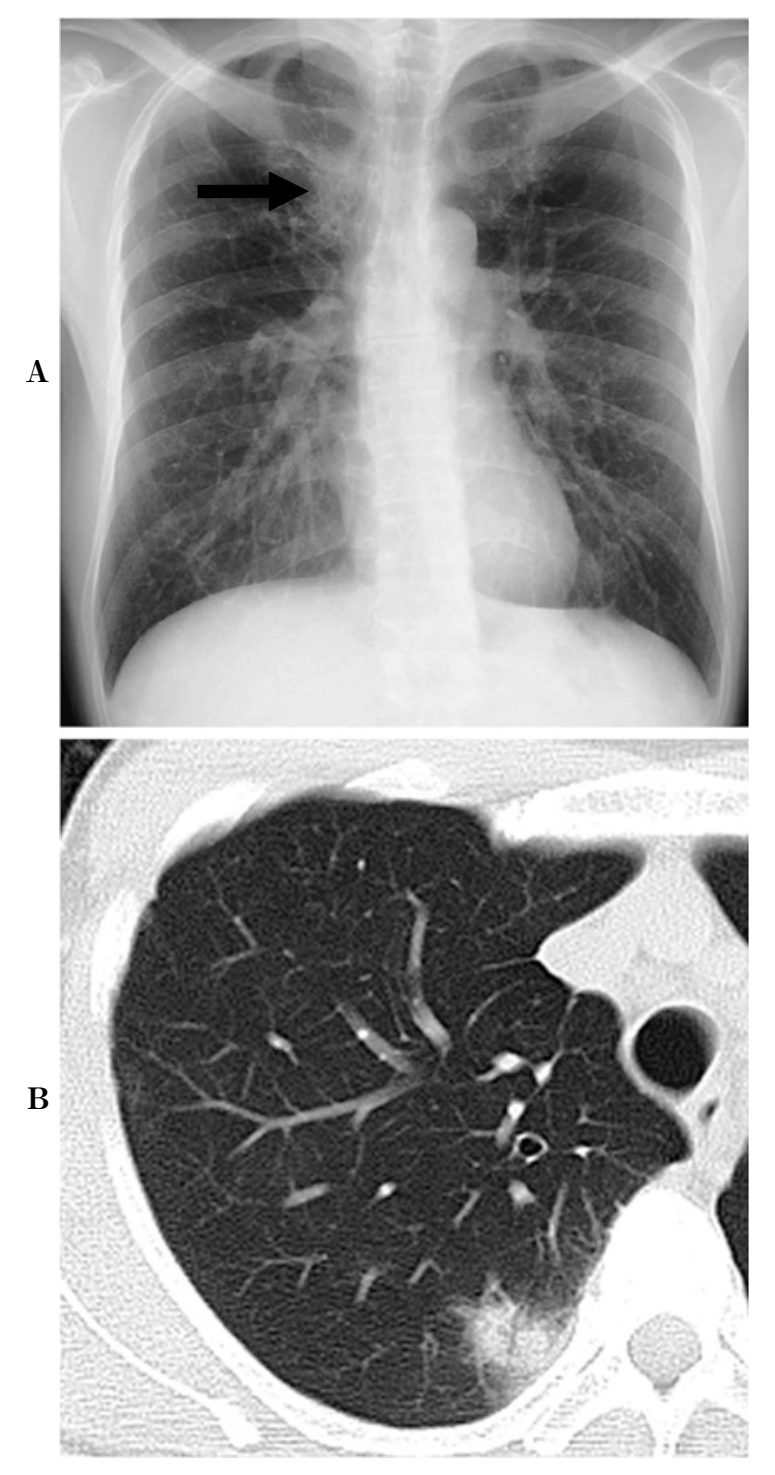

Figure 1. An abnormal shadow overlapped by bones.

\section{ながら概説する.}

\section{1. 胸部 $X$ 線写真のピットフォール}

肺病変は肺野の含気が軟部濃度で置き換えられるの で，X線写真では透過性が低下して白く見える．この白 く見える結節と黒く見える透過性の高い周囲含気の濃度 差を見つけることで, 病変が検出できる. 肺結節の見落 としには, 不注意による見落としと胸部 X 線写真で検出 しにくい領域に生じたための見落としがある。結節と周 囲含気の濃度差が弱い領域は病変を見つけにくく, 胸部 $\mathrm{X}$ 線写真では肺野以外の正常臓器と重なる部位がこれに 相当する。縦隔あるいは肝臓と重なる領域や，複数の骨 が密集する肺尖部などである，肺結節ではないが気管腫 瘍も正面像では捉えにくいことがある. 病変を見つけに
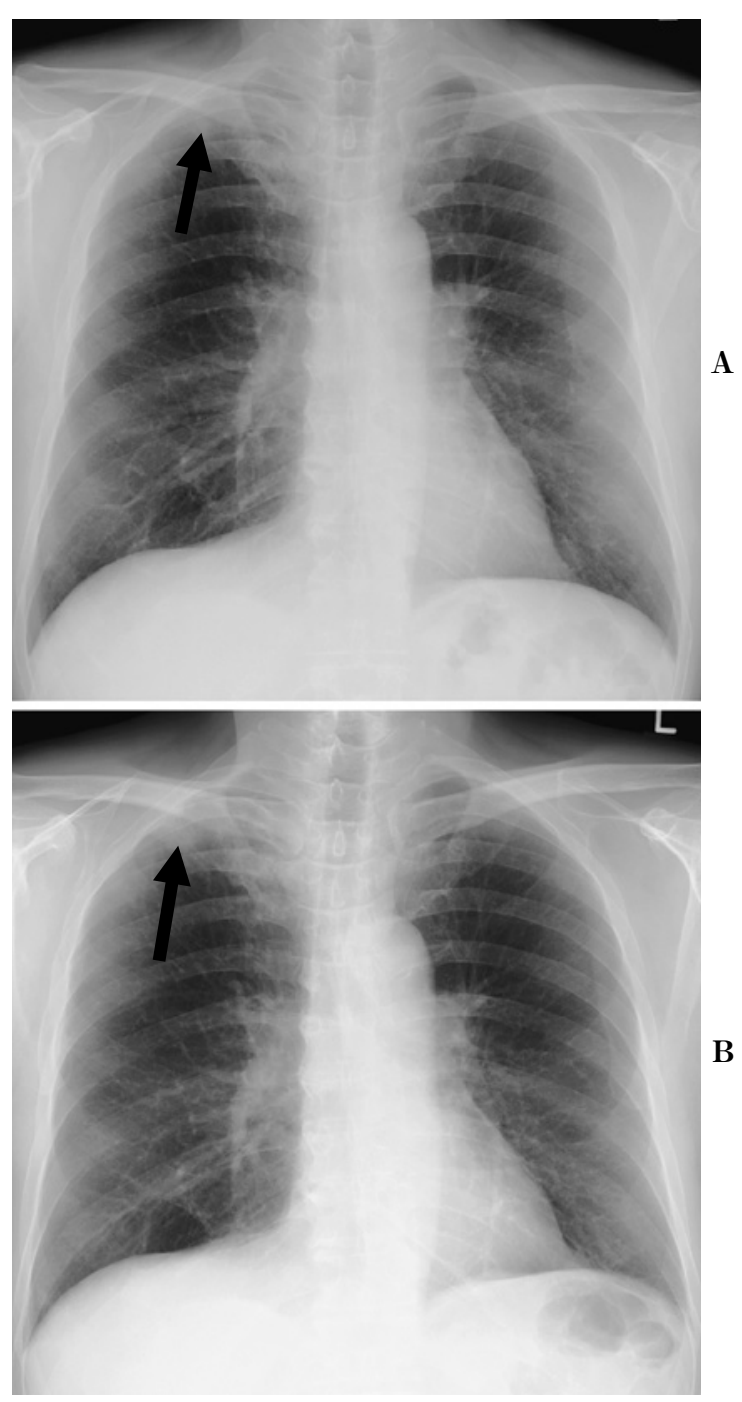

Figure 2. Small lung cancer in the apex.

くいこれらの領域の存在を認識しておくことは重要で, わずかな濃度差を注意深く観察することで病変を拾い上 げることが可能になる．側面写真では正面写真で見つけ にくい部位の結節が明確に描出されることがあるので, 側面写真の正常像を理解しておくことは大切である。過 去画像と比較することも病変の検出と良悪性判定に役立 つ.

\section{・複数の骨に重なる肺野陰影（Figure 1)}

右鎖骨近位, 第 1 肋骨前部, 背部第 4 および第 5 肋骨 に重なる位置に異常陰影が見られるが (Figure 1A), 見 つけにくい. 左右差を注意深く観察することが大切であ る. CT (Figure 1B) では, 病変の背腹方向に複数の骨が 存在していることがよくわかる.

・肺尖の小さな肺癌 (Figure 2)

右肺尖に第 1 肋骨と重なる小さな結節 (Figure $2 \mathrm{~A}$ 矢印) を認めるが, 見つけにくい. 

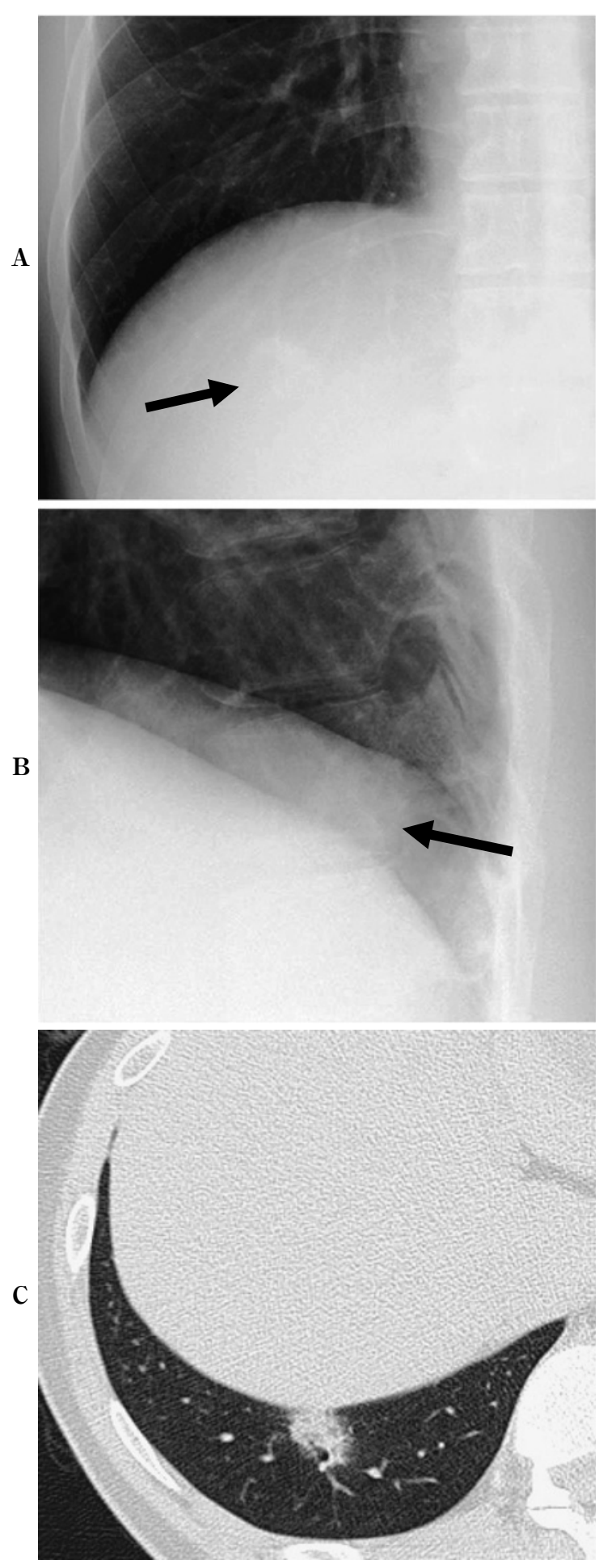

Figure 3. Lung nodules in the lung base.

3 年後の胸部 X 線写真で結節 (Figure $2 B$ 矢印) は増大 し, 検出は容易である.

\section{・肺底部の結節影（Figure 3)}

正面像 (Figure 3A) で右肺底部で肝臟に重なって結節 (矢印)が見られるが, 濃度差がほとんどなく病変検出は
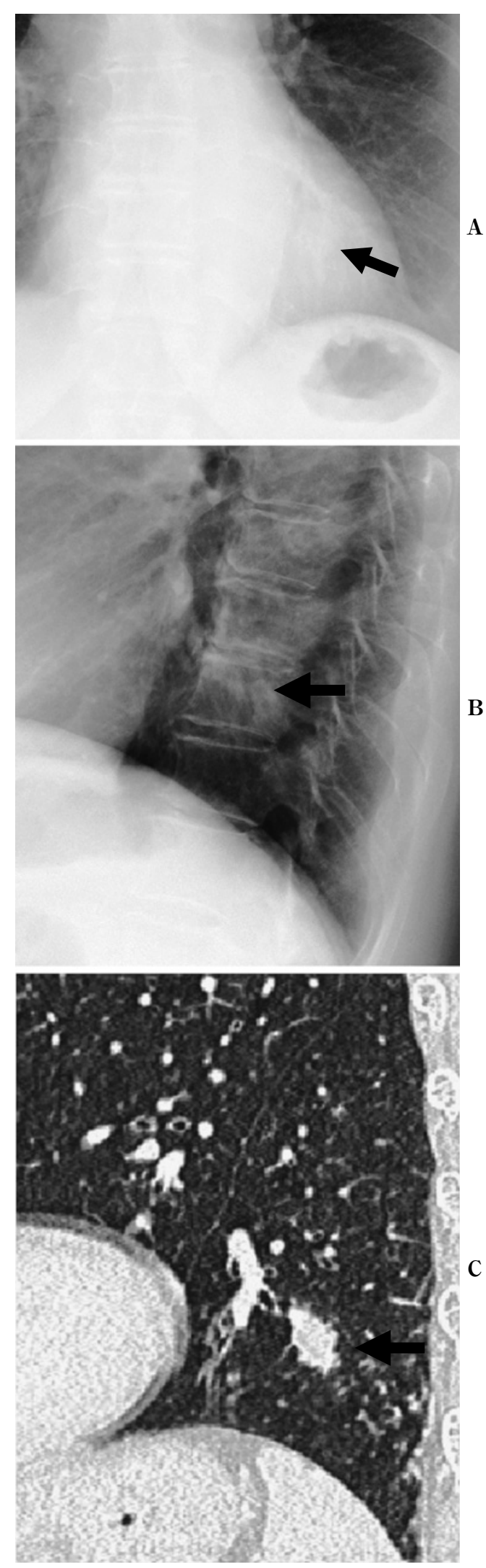

Figure 4. An abnormal shadow overlapped by the heart on a posteroanterior chest radiograph. 

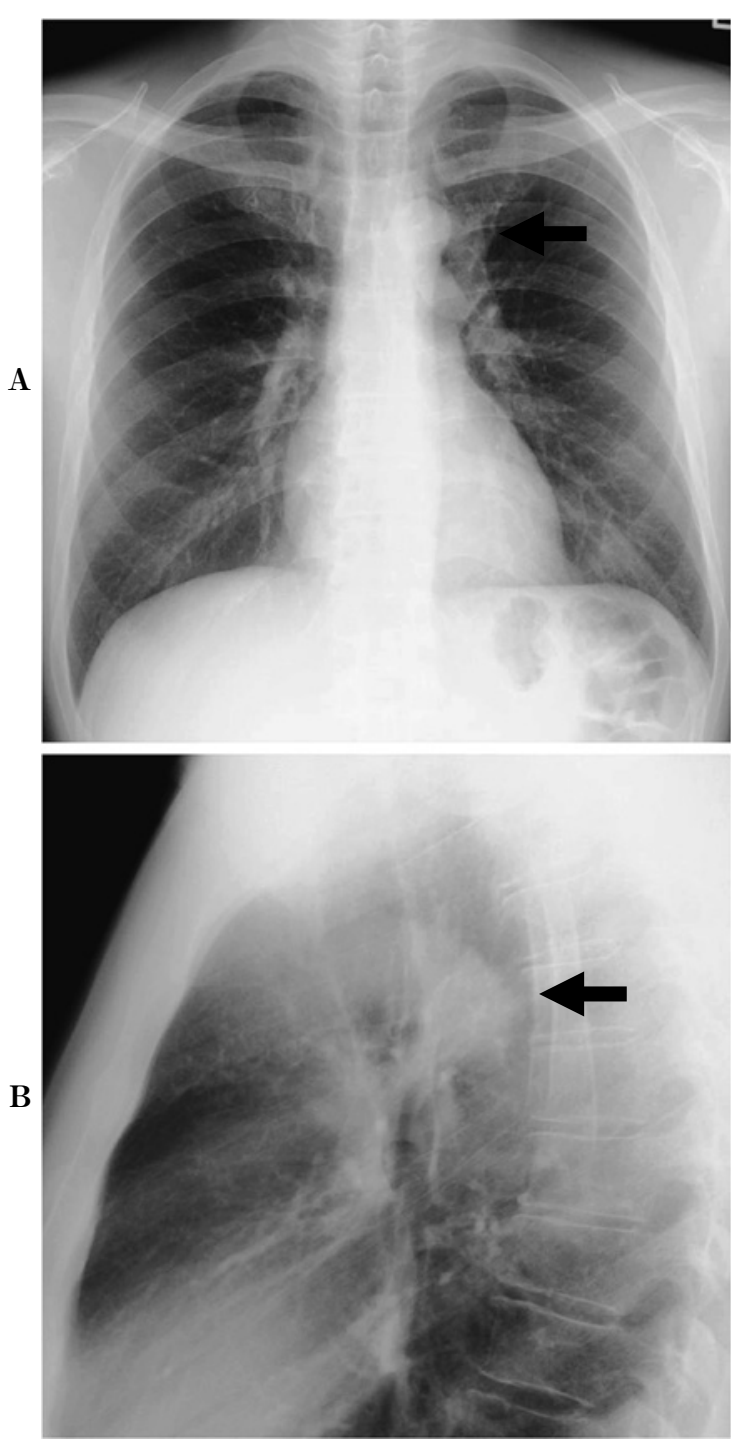

Figure 5. Lung cancer overlapped by the mediastinum on a posteroanterior chest radiograph.

困難である。側面像（Figure 3B）で結節（矢印）の認識 は可能である，側面像をもとに正面像を見直すと横隔膜 下の異常影がわかりやすい. CT (Figure 3C) で右肺底部 結節が確認される.

\section{・心陰影と重なる肺癌（Figure 4)}

正面像 (Figure 4A）で結節（矢印）の検出は難しい. 側面像 (Figure 4B) でも見慣れていないと見落とされる ほどの結節 (矢印) である。CT 再構成矢状断像 (Figure 4C)で, 左下葉に扁平型の結節を認める. CT 所見から胸 部 X 線写真を見直すことで胸部 X 線写真の読影能力は 向上するので，習慣にすると良い.

\section{・縦隔影に重なる肺癌（Figure 5)}

正面像 (Figure 5A) で左上肺野内側に結節影が見られ る(矢印)。肺動脈と見間違え得るが, 左右肺野を見比べ

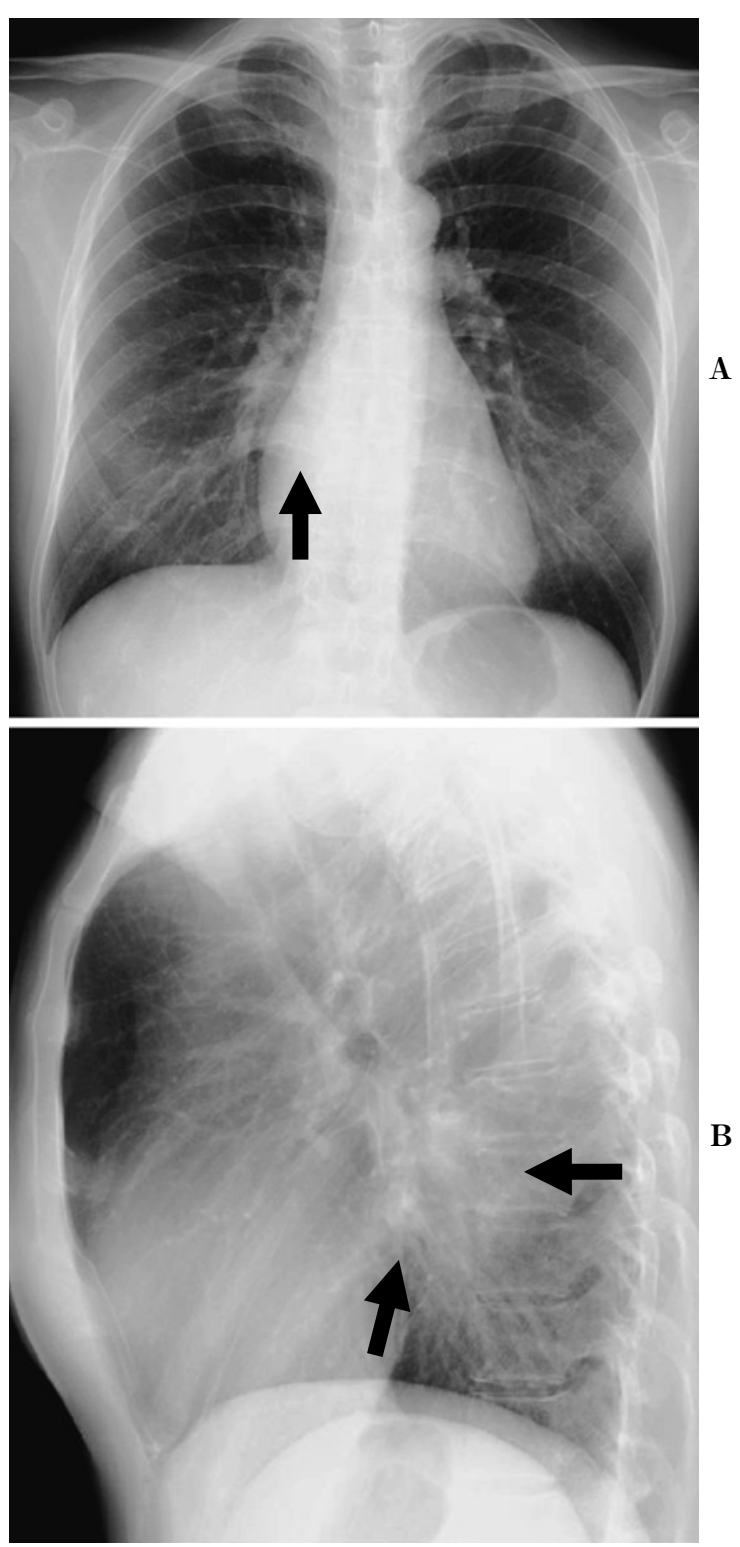

Figure 6. Lung cancer overlapped by the mediastinum and hilum on the posteroanterior chest radiograph.

ると異常は明らかである。側面像 (Figure 5B) では大動 脈弓部に重なる部位に高濃度結節を認める (矢印).

\section{・縦隔影と肺門に重なる肺癌（Figure 6)}

正面像 (Figure 6A) で右肺門下部と心㓌影に重なる位 置に異常影が見られる (矢印)。心陰影に重なる部位では 濃度差が少なく，注意がいる，側面像 (Figure 6B) で心 後面に透過性低下域が見られ (矢印), 異常所見である.

\section{- 気管腫瘍 (Figure 7)}

気管の前後方向には胸骨, 椎体, 食道, 血管, 筋など が存在するために, 正面写真では気管病変の濃度差は少 なく，注意深く観察しないと気管腫瘍を見落とすことが 

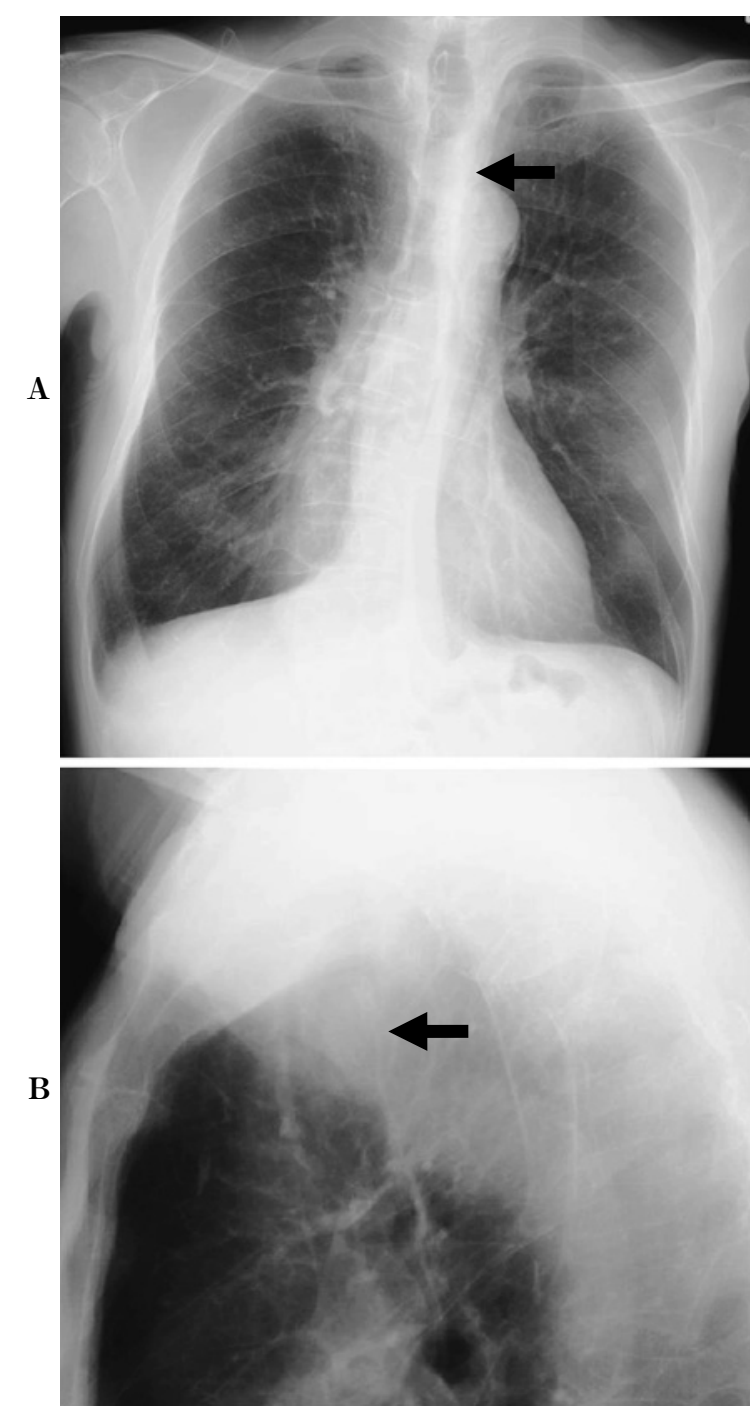

Figure 7. A tracheal tumor.

ある. 気管の形態変化を認識することも大切である. 正面像 (Figure 7A) で気管狭窄 (矢印) が見られるが, 胸骨, 椎体, 血管と重なるので濃度差としては認識しが たい. 常日頃から気管形態を確認する習慣があれば形態 異常として捉えることができる．側面像（Figure 7B）で 高濃度の気管腫瘍が認識できる (矢印).

\section{2. 肺結節と見誤りやすい所見}

胸部 X 線写真において肺結節と見誤りやすい解剖学 的正常構造物, 正常破格, 生理的変化を知り, それらの 画像的特徴を理解しておくことは, 過剩な CT 精查など を省き医療の質向上に寄与する，以下に代表的症例を供 覧し解説する。

\section{- 第 1 肋軟骨骨化}

第 1 肋軟骨の石灰化は 20 歳頃から始まり, 単純写真で

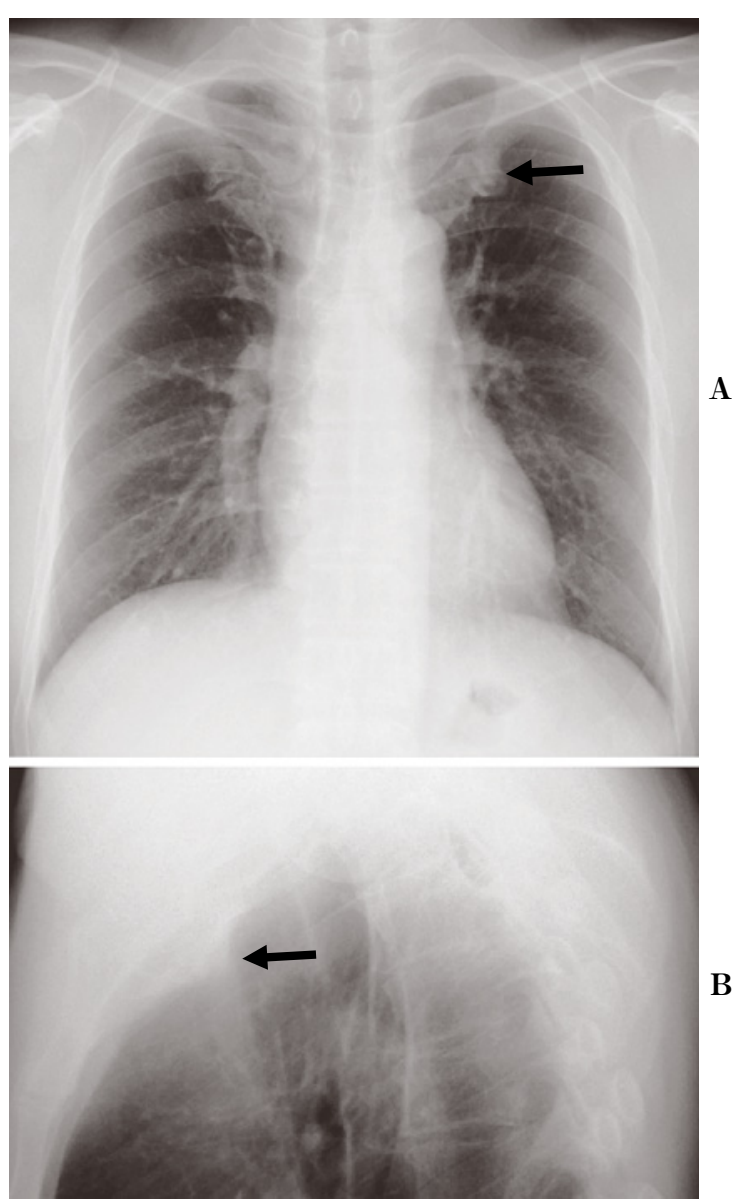

Figure 8. Ossification of the first rib cartilage.

確認できるようになる. 胸部 X 線写真で日常よく遭遇す る所見で, student's tumor と呼称されるほど初学者が肺 結節と誤認しやすい病変である. 第 1 胁骨の骨部と軟骨 部の結合部骨性増殖が本態で, 正面像では中心に関節裂 隙を有する円形, 類円形の結節影として見られる（Figure 8A). 側面像の所見は前上部胸壁から肺内に向かう 骨性突出で (Figure 8B), 肺内に位置していないことがわ かる．両側対称性に見られる場合には診断は比較的容易 であるが，骨化程度に顕著な左右差がある場合や片側性 では肺結節と間違わないように注意がいる，上肺野の結 節が正面像で第 1 肋軟骨骨化部に重なることがあるの で，側面像は鑑別に有用である。

\section{- 乳頭陰影}

下肺野に乳頭陰影が円形結節として見られることがあ る (Figure 9A). 左右対称性に見られることが多いが, 片側に見られると肺結節と鑑別する必要がある。撮影時 の乳頭と撮影装置の密着度により，描出のされ方は同一 患者でも様々である. 撮影装置との密着度が強い場合に は乳頭の一部が平坦化し, 平坦化した辺縁は X 線写真で 不鮮明に描出される (Figure 9B 矢印)。これをincom- 

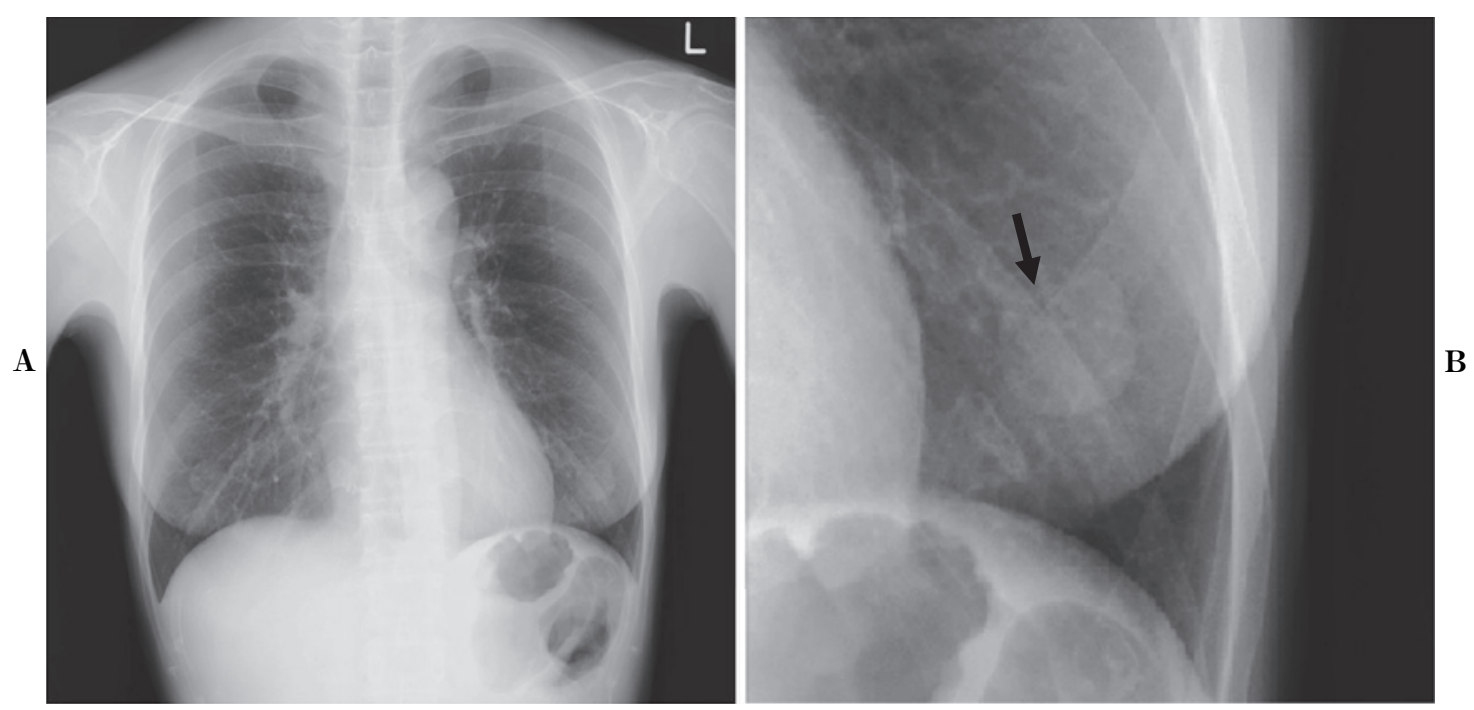

Figure 9. A nipple shadow.
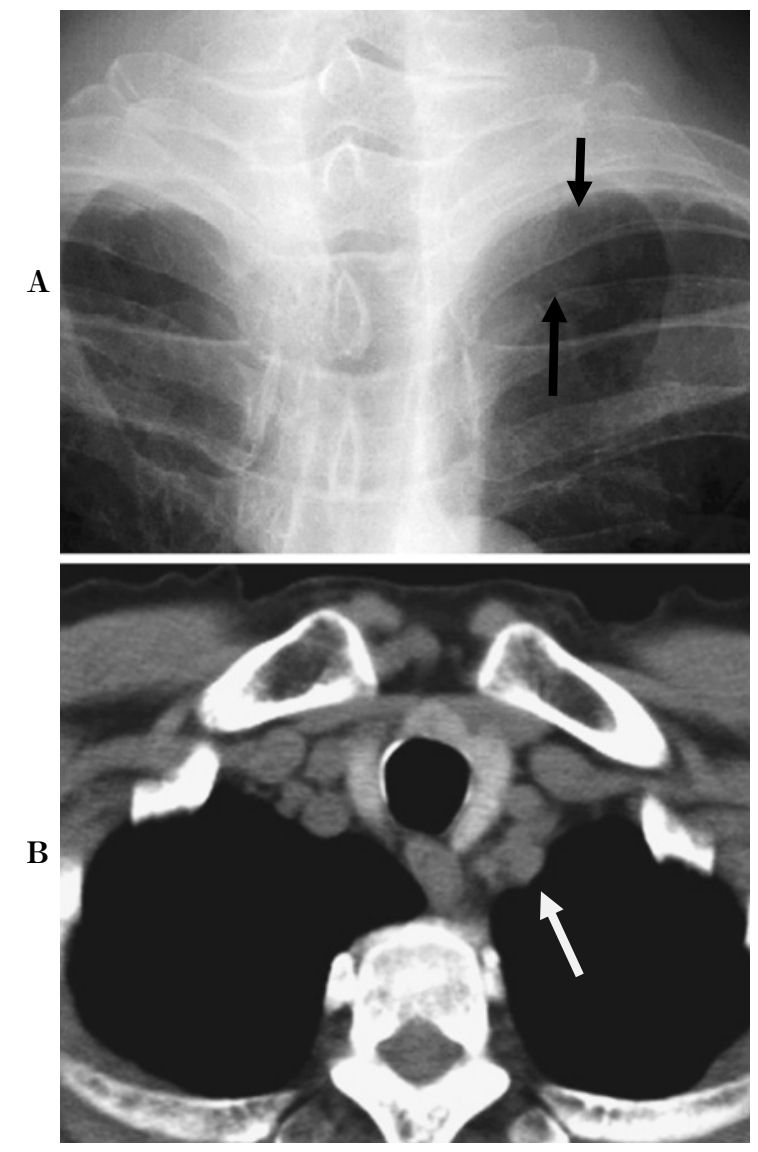

Figure 10. Apical opacity.

plete border sign と呼ぶ. 1 側面像では前胸壁に乳頭が 観察でき，肺内に位置していないことを確認できる。た だし側面像では両上肢挙上での撮影となるため乳頭位置 は正面像より高くなり得る。
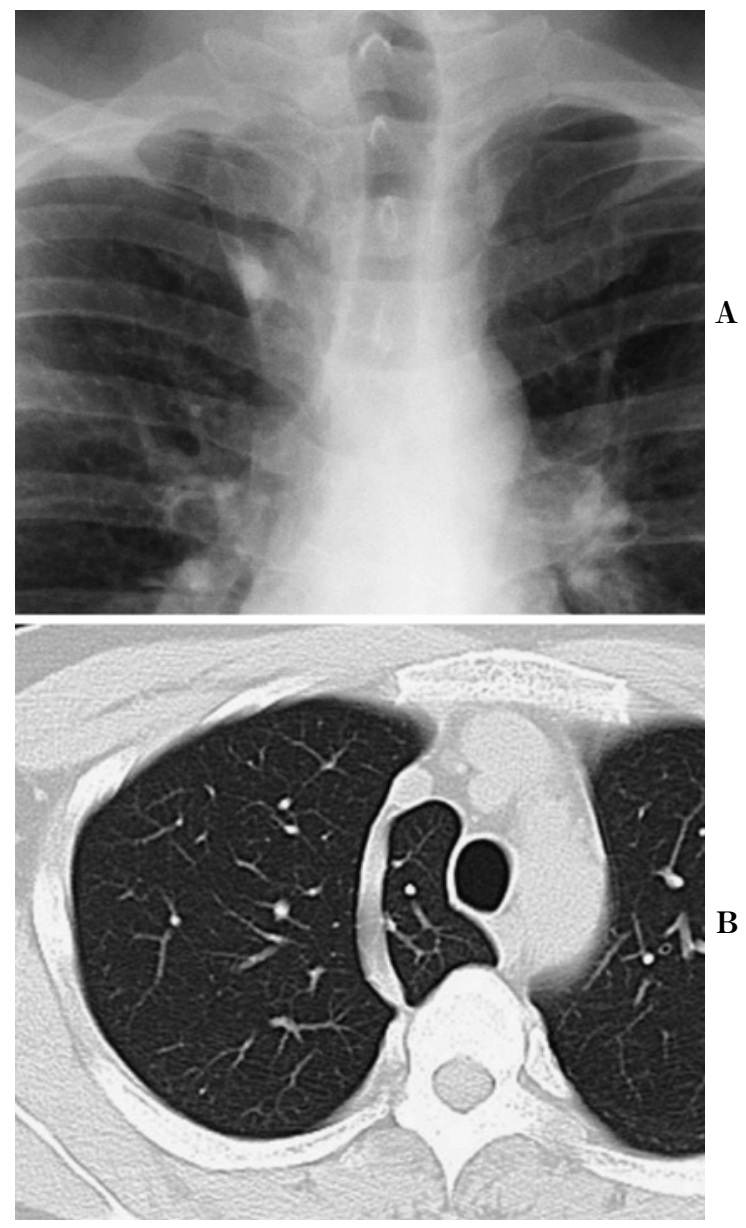

Figure 11. An azygos lobe.

\section{- Apical opacity}

肺尖の境界不鮮明な淡い卵円形結節影で, 第 1 肋骨内 

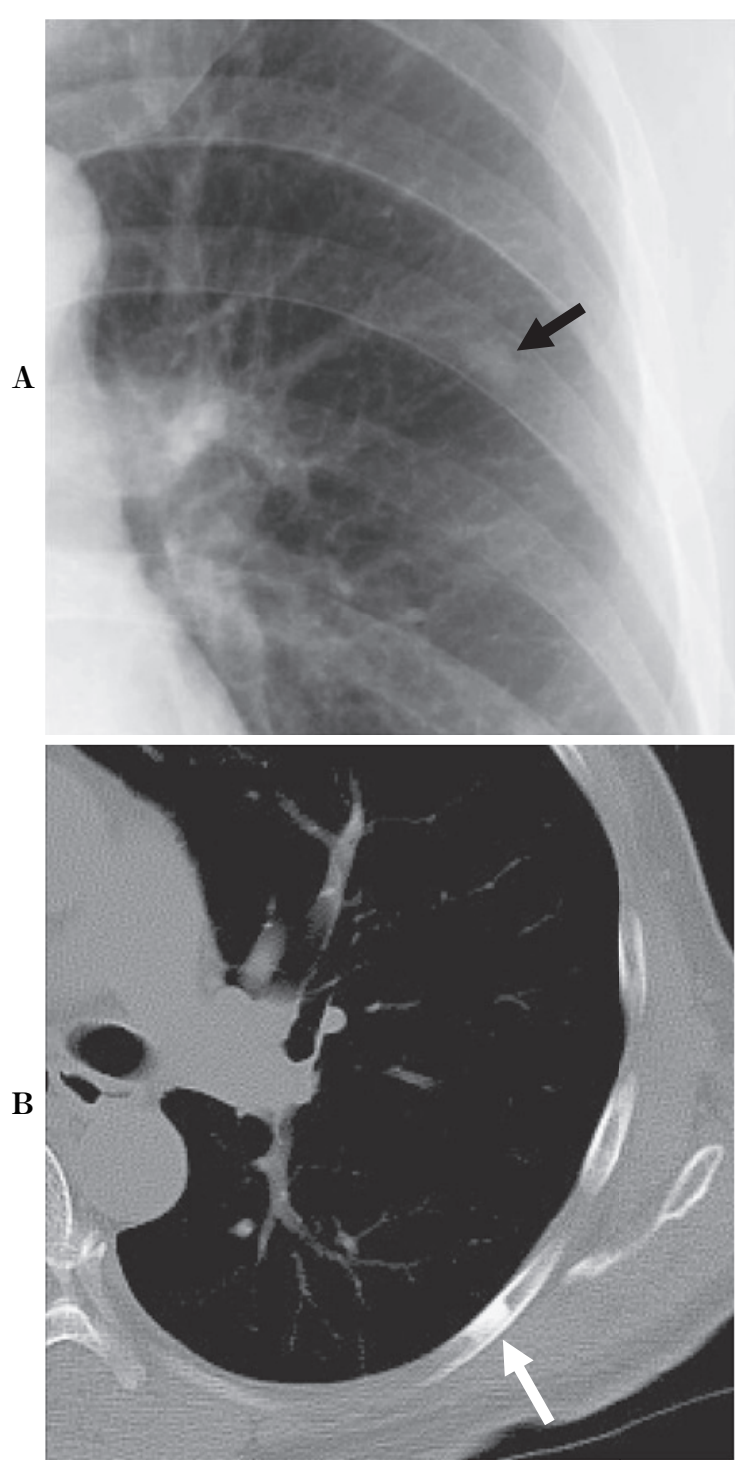

Figure 12. A bone island.

側縁と胸椎外側縁の中央で後部第 2 , 第 3 肋間に見られ る (Figure 10A)。鎖骨下動脈の apical portion が肺に深 く入り込んでいるために生じる陰影である（Figure $10 \mathrm{~B}$ 矢印). 2 日本人の $3.7 \%$ で認められると報告されて おり, 3 欧米人より描出される頻度は少ない.

\section{- 奇静脈葉}

奇静脈が右肺尖部を横切り前方に走行して上大静脈に 注ぐことが成因で， 4 枚の胸膜 $(2$ 枚の臟側胸膜と 2 枚の 壁側胸膜）が奇静脈により引っ張られることで形成され る. 胸部 X 線写真正面では奇静脈が涙滴状の結節として 見られ, 引っ張られた胸膜は奇静脈と連続する線状影と して認められる (Figure 11). 4

\section{・骨島}

骨島 (bone island) は enostosis とも呼ばれ，骨髄㠿に
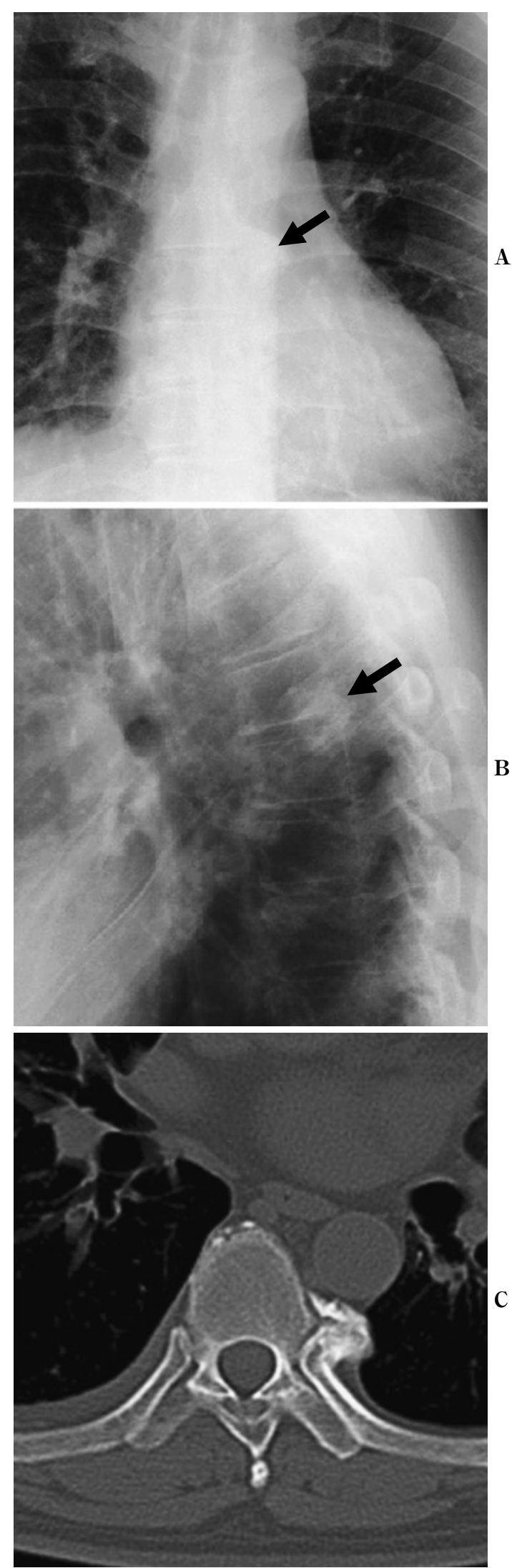

Figure 13. Osteophyte formation in the joint of rib head. 


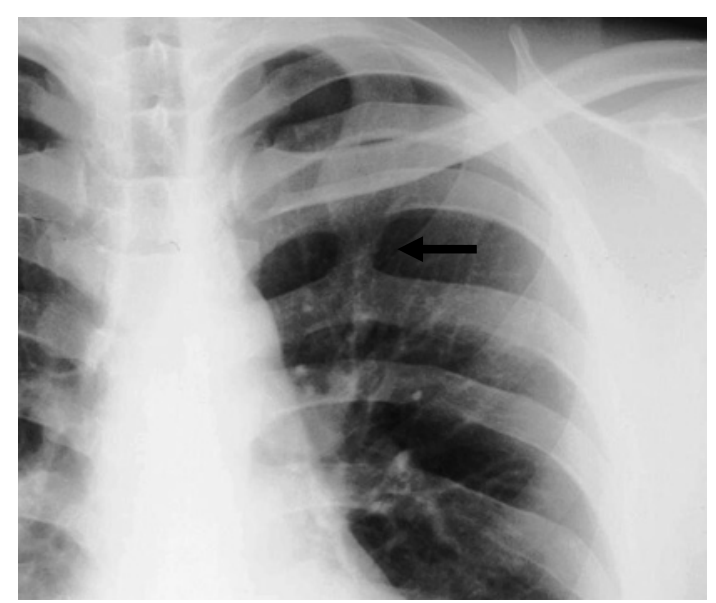

Figure 14. A rib anomaly: bridge formation.

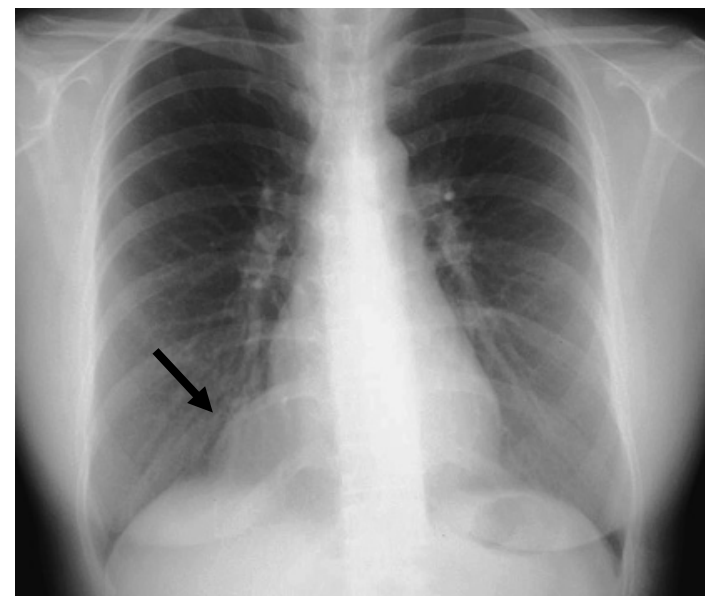

Figure 15. A pericardial fat pad.

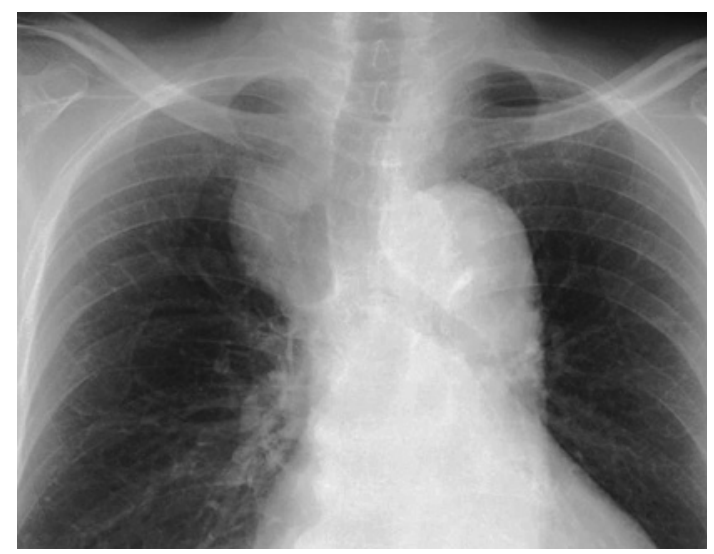

Figure 16. A tortuous and elongated right brachiocephalic artery.

残存した緻密骨である. 5 病的意義はないが, 日常臨床で は肺結節と紛らわしいため CT が行われることがまれで

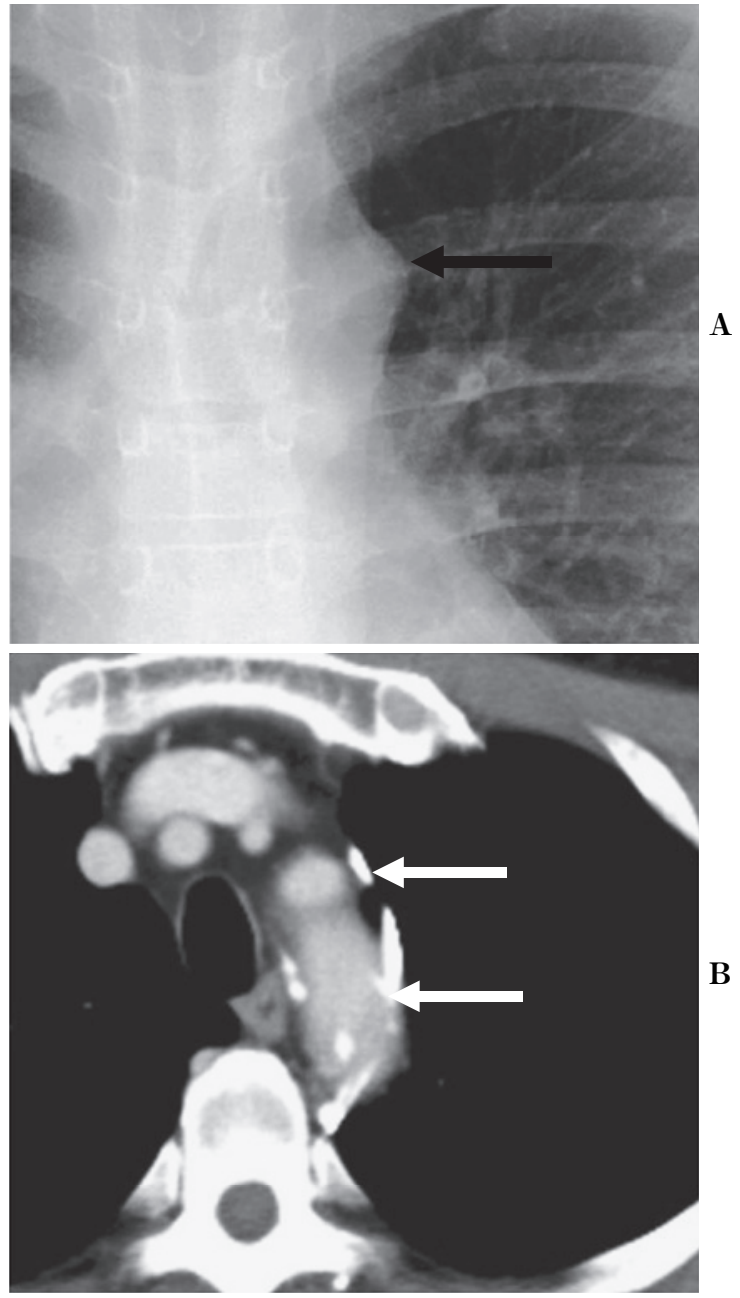

Figure 17. An aortic nipple.

はない. X 線写真では限局性の均一な硬化像として描出 され, 辺縁は平滑である. 胁骨の骨島は肋骨長軸に沿っ て位置する (Figure 12).

\section{・肋骨頭関節骨棘}

胁骨頭関節は肋骨頭と胸椎椎体肋骨窩の関節で, 胁骨 頭関節骨棘は類円形の硬化像として見られる. 正面像で は椎体辺縁から突出する陰影として見られ（Figure 13A), 側面像では椎間腔後方の上下椎体肋骨窩に重なる 除影として認められる（Figure 13B）.

\section{3. 異常影を見極めるために知っておきたい偽病変}

画像診断でなんらかの所見を拾い上げたとき, その所 見が真の病変なのか偽病変なのかを正しく判断すること は大切で, 真病変であれば適切な治療方針を早期に決定 でき，偽病変であれば以降の無駄な検査を省くことがで きる．偽病変であると自信を持って診断するためには多 くの画像を見て多様な偽病変を経験しておくと良い。偽 


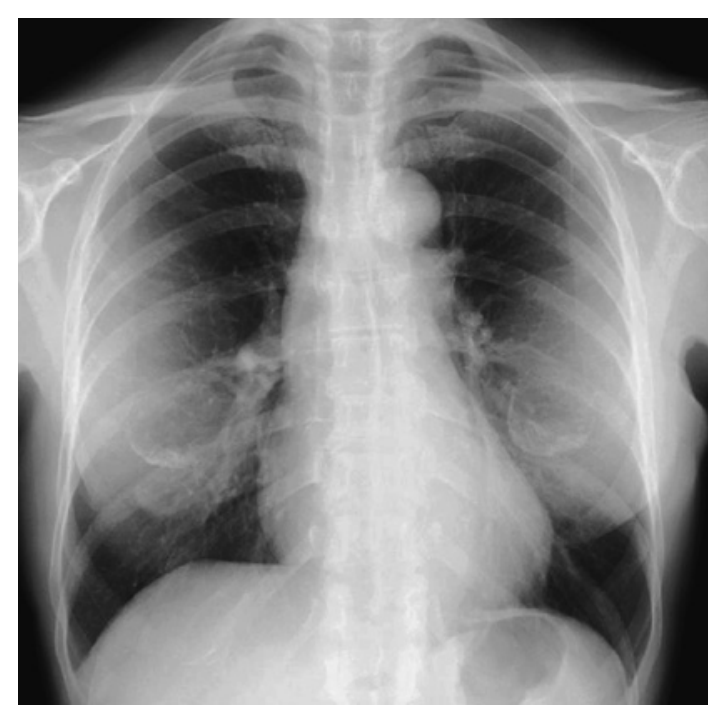

Figure 18. Calcification of mammary implants.

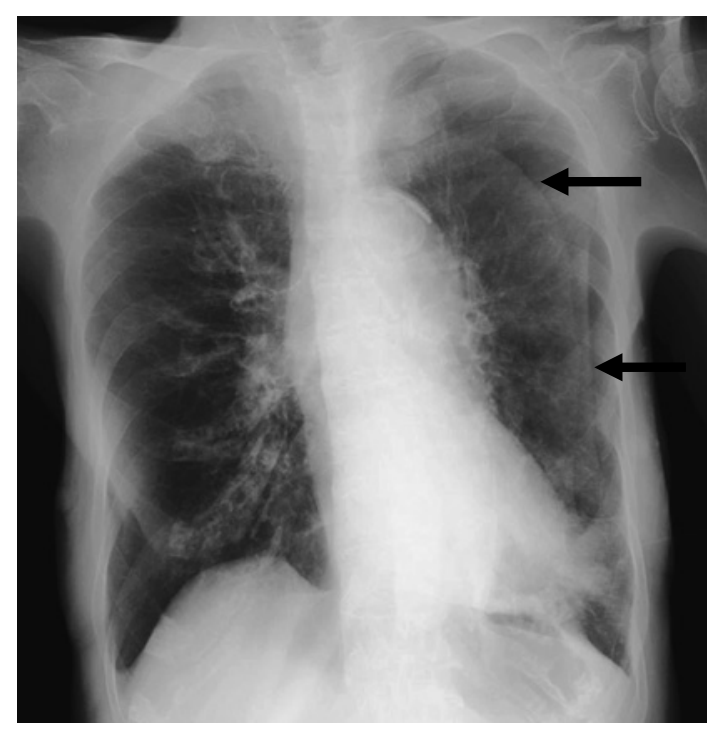

Figure 19. A skin fold.

病変には, 正常破格, 奇形, 変形, 異物, $\mathrm{X}$ 線撮影特有 の所見などがある．以下に偽病変をいくつか紹介する.

\section{- 肋骨奇形}

肋骨奇形には, 形成不全, 融合, 分岐, 橋形成など様々 な奇形がある. 日常臨床で問題になることは通常ないが, 存在部位や形態によっては肺野病変や胸壁病変と見誤る ことがある (Figure 14).

\section{- 心膜外脂肪塊（pericardial fat pad）}

加齢や肥満などが原因で心膜外の脂肪沈着が多くなる と, 心横隔膜角の腫瘤様陰影として見えるようになる (Figure 15)，心横隔膜部の腫瘤様陰影の鑑別は，心膜外 脂肪塊のほかに, 心膜囊胞, 縦隔腫瘍, 横隔膜ヘルニア,

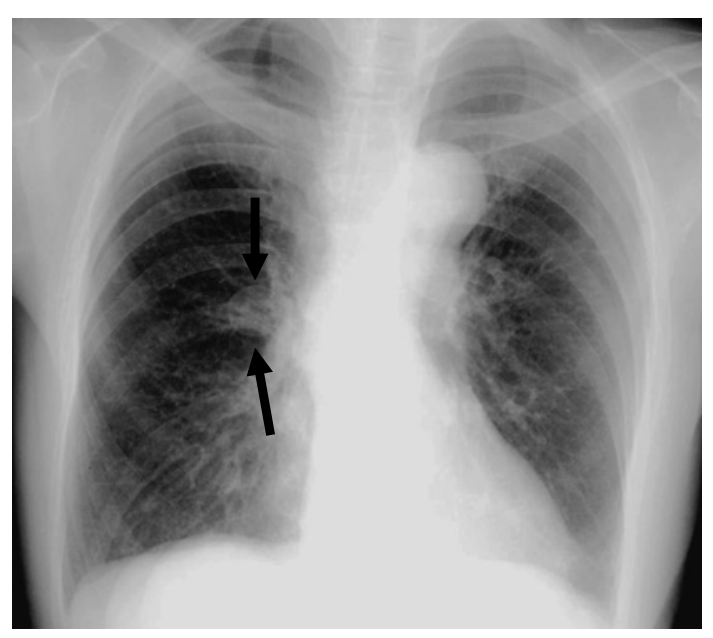

Figure 20. An object on the skin.

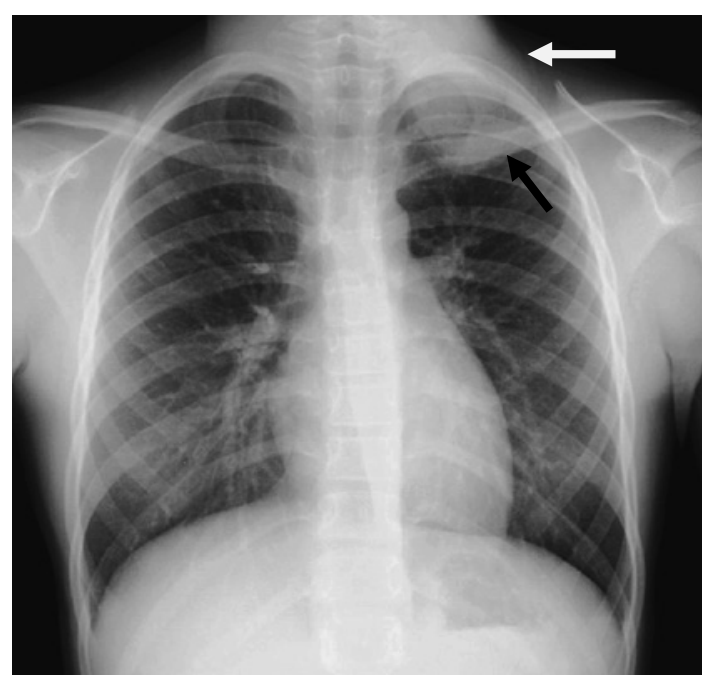

Figure 21. A hair shadow.

横隔膜弛緩症などである. ${ }^{6}$ 脂肪の X 線透過性は腫瘍や 水よりも高いため, 腫瘍などよりも低濃度陰影として胸 部 X 線写真では描出される.

\section{- 腕頭動脈の蛇行, 延長}

加歯令や動脈硬化が進行すると, 右腕頭動脈の蛇行と延 長を生じ得る. 蛇行した右腕頭動脈は, 胸部 X 線写真正 面像で右上葉肺腫瘍や縦隔腫瘍と鑑別を要することがあ る(Figure 16). 院影による気管圧迫はなく, 澒胸部徵候 は陽性である。

\section{- Aortic nipple}

大動脈弓部の外側縁を走行する左最上胁間静脈による 院影である (Figure 17). 7 胸部 X 線写真正面像で大動脈 弓から突出する隆起として認められ (Figure 17A), aortic nipple と呼ばれる. 傍大動脈リンパ節腫大や大動脈瘤 
と見䛊ることがある.

\section{-人工乳房石灰化}

人工乳房充填物のシリコン被膜周囲に反応性に形成さ れた線維性被膜構造が石灰化すると, $\mathrm{X}$ 線写真でリング 状石灰化病変として描出されるようになり (Figure 18), 包虫症などの石灰化病変と見間違え得る。側面像は肺病 変との鑑別に有用であるが, 臨床情報が最も大切である.

\section{・皮膚㱀}

高齢者では胸部 X 線写真撮影時に皮膚の㱀が生じて 画像に投影されやすい. 片麻痺患者や乳房切除後患者な どでは胸壁軟部組織が非対称となり，㱀が目立つことが ある，縦走する㱀は気胸と見䛊ることがある（Figure 19). 横走すると無気肺や肺炎と見間違えることがある.

\section{・皮膚上の異物}

簡易夕イプのお尒などは撮影時に気づかれないことが ある．人工的な陰影であるが, 正面像のみでは異物の位 置によっては肺腫瘍や縦隔腫瘍と見間違え得る（Figure 20).

\section{- 頭髮}

束ねた頭髪が上肺に重なり肺病変と紛らわしいことが あるが, 頭髪なので陰影の頭側が胸郭外に連続している ことを確認できれば肺病変と間違えることはない（Fig- ure 21). 本来は撮影現場で気づかれるべきである.

本論文内容に関連する著者の利益相反：なし

\section{REFERENCES}

1. Hsu CC, Henry TS, Chung JH, Little BP. The incomplete border sign. J Thorac Imaging. 2014;29:W48.

2. Proto AV, Chaliff MI. Apical opacity: a normal finding on posteroanterior chest radiographs. Radiology. 1986;161: 429-432.

3. Abiru H, Ashizawa K, Hashmi R, Hayashi K. Normal radiographic anatomy of thoracic structures: analysis of 1000 chest radiographs in Japanese population. $\mathrm{Br} J \mathrm{Ra}$ diol. 2005;78:398-404.

4. Mata J, Cáceres J, Alegret X, Coscojuela P, De Marcos JA. Imaging of the azygos lobe: normal anatomy and variations. AJR Am J Roentgenol. 1991;156:931-937.

5. Greenspan A. Bone island (enostosis): current concept--a review. Skeletal Radiol. 1995;24:111-115.

6. Pineda V, Andreu J, Cáceres J, Merino X, Varona D, Domínguez-Oronoz R. Lesions of the cardiophrenic space: findings at cross-sectional imaging. Radiographics. 2007;27:19-32.

7. Cole TJ, Henry DA, Jolles H, Proto AV. Normal and abnormal vascular structures that simulate neoplasms on chest radiographs: clues to the diagnosis. Radiographics. 1995;15:867-891. 